\title{
Waterlogging effects upon the phenological phases of common bean cultivar BRSMG-Uai
}

\section{Efeitos do alagamento nas fases fenológicas da cultivar de feijão comum BRSMG-Uai}

\author{
Beatriz Gonçalves Pereira Costa1 ${ }^{1}$, Bárbara Christina Silva Amâncio' ${ }^{(D)}$, Lissa Vasconcellos Vilas Boas ${ }^{1}$ (D), \\ Ludmila da Silva Bastos ${ }^{1}$ (D), Debora Domiciano' ${ }^{1}$, Paulo Eduardo Ribeiro Marchiori*(D)
}

'Universidade Federal de Lavras/UFLA, Departamento de Biologia/DBI, Lavras, MG, Brasil

*Corresponding author: paulo.marchiori@ufla.br

Received in April 14, 2020 and approved in August 31, 2020

\begin{abstract}
Common bean (Phaseolus vulgaris L.) is an important source of protein and carbohydrates, besides being rich in several mineral nutrients. In a flooding situation, the low availability of oxygen may result in hypoxia or anoxia condition. Therefore, this study aimed to evaluate the responses of the common bean cultivar BRSMG-Uai subjected to hypoxia in different phenological phases, analyzing its responses in terms of growth, productivity, carbon and nitrogen metabolism. Thus, seeds of common beans were germinated and when the seedling reached growth stage $\mathrm{V} 1$, they were transferred to plastic boxes containing $40 \mathrm{~L}$ of nutritive solution with steady aeration. Distinct series of plants were exposed to air-restriction on their roots for nine days, in three different phenological phases V3/V4, R6 and R7. Samples were collected for biochemical and growth analyses in a completely random design $(n=6)$. The plants subjected to low availability of oxygen presented a reduction in bean number, displaying the greatest loss in productivity in V3/V4, conferring the highest sensitivity to hypoxia in this phase. On the other hand, there was an increase in sugar concentration in leaves, and it was also possible to observe an increase in hydrogen peroxide in leaves and roots, concomitant with a decrease in superoxide dismutase activity in all phenological phases. There was also an increase in ascorbate peroxidase activity in roots in R6, as well as in nitrate reductase activity. We conclude that the cultivar BRSMG-Uai presents sensitivity to low oxygen availability, and the phenological phaseV3/V4 is the most critical for it.
\end{abstract}

Index terms: Hypoxia; Phaseolus vulgaris L.; nitrogen metabolism.

\begin{abstract}
RESUMO
O feijão comum (Phaseolus vulgaris L.) é uma leguminosa importante por ser fonte de proteína, carboidratos e rico em vários minerais. Em situação de alagamento, a disponibilidade de oxigênio pode proporcionar uma condição de anoxia ou hipóxia. O presente trabalho teve como objetivo avaliar o comportamento da cultivar BRSMG-Uai submetida a hipóxia em diferentes fases fenológicas, analisando as respostas em relação ao crescimento e produção, metabolismo de carboidratos e assimilação de nitrato. Desta maneira, sementes de feijão comum foram semeadas e ao atingirem o estádio de desenvolvimento V1 foram transferidas para recipientes contendo 40L de solução nutritiva e aeração constante. As plantas foram expostas a condição de falta de aeração por 9 dias, em três diferentes fases fenológicas. Foram consideradas as fases fenológicas V3/V4, R6 e R7. Após as coletas foram realizadas análises bioquímicas e de crescimento, com delineamento inteiramente casualizado $(n=6)$. Plantas submetidas a baixa disponibilidade de oxigênio apresentaram redução no número de grãos, sendo em V3/V4 a maior perda em produção conferindo maior sensibilidade a hipóxia nesta fase. Em contrapartida, ocorreu aumento na concentração de açucares nas folhas. Foi possível observar nas folhas e raízes, aumento no conteúdo de peróxido de hidrogênio, redução da atividade da enzima dismutase do superóxido nas fases fenológicas V3/V4, R6 e R7, aumento da atividade da enzima peroxidase do ascorbato nas raízes em R6 e da atividade da enzima redutase do nitrato. Conclui-se que a cultivar BRSMG-Uai apresentou sensibilidade a baixa disponibilidade de oxigênio, e que a fase fenológica V3/V4 é a mais crítica.
\end{abstract}

Termos para indexação: Hipóxia; Phaseolus vulgaris L.; metabolismo de nitrogênio.

\section{INTRODUCTION}

Global climate changes tend to worsen problems related to rain patterns in many regions in the world and this may probably lead to increase floods and soil waterlogging (Debortoli, 2017; Hirabayashi et al., 2013). The flooding, caused by either too much rain or even irrigation in poorly drained soils, is one of the abiotic stresses that most affect crop productivity (Choudhury et al., 2013), once induces lower oxygen availability to the radicular system. Based on the height of the water column, the inundation may be classified as (i) waterlogging, when water covers only the 
roots or (ii) flooding, when the water covers partially or completely the shoot (Sasidharan et al., 2017). The aerobic respiration of plants and microorganisms in such condition additionally reduces the soil oxygen concentration, leading to hypoxia (low oxygen concentration $<21 \%$ ) or, in more extreme conditions, anoxia (absence of oxygen) (Lee et al., 2011; Sasidharan et al., 2017).

Soil waterlogging causes a hypoxic environment that will eventually affect the plant metabolism through changes in parameters related to photosynthesis, energy production, synthesis and transport of ions and molecules, that is, activities that require metabolic energy. Photosynthesis inhibition happens mainly by reducing the $\mathrm{CO}_{2}$ absorption, due to stomatal closure, limiting the Calvin cycle and mitochondrial ATP production (Zhang et al., 2016). Meanwhile, in the roots, there is also a lower cell energy production, restricting the absorption of water and nutrients; furthermore, the inhibition of aerobic respiration results in an increase of lactate and ethanol in the cell cytosol (Perez-Jimenez, 2017; Dumont; Rivoval, 2019). In this case, the enzyme nitrate reductase (NR), which is in charge of reducing nitrate into nitrite, may become an alternative pathway to act in the regeneration of the reducing power $\mathrm{NAD}^{+}$(Fukao et al., 2019).

Besides those damages, there is an increase in reactive oxygen species (ROS) formation, indicating oxidative damage that directly affects the maintenance of cell homeostasis, causing damages to proteins, lipids, carbohydrates and nucleic acids (DNA and RNA) (Lal et al., 2019). Among the most important ROS stand out the superoxide anion $\left(\mathrm{O}_{2}^{-}\right)$, hydrogen peroxide $\left(\mathrm{H}_{2} \mathrm{O}_{2}\right)$, and the hydroxyl radical $\left(\mathrm{OH}^{-}\right)$that in conditions of hypoxia accumulates in the leaves along with an increase in malondialdehyde (MDA) (Fukao et al., 2019). Those situations demand that the plant resort to biochemical and morphological changes to assure their survival. In this case, one of the strategies is to minimize the damages caused by the excess of those free radicals by producing redox enzymes that scavenge the ROS. Superoxide dismutase (SOD), ascorbate peroxidase (APX) and catalase (CAT) outstand among those enzymes (Dumont; Rivoval, 2019).

The common bean (Phaseolus vulgaris L.) is a very important culture for Brazilians nutrition since it is an important source of proteins, carbohydrates and naturally rich in mineral nutrients (Carbonell et al., 2014). The average productivity and consumption are $1.6 \mathrm{tha}^{-1}$ and $16 \mathrm{~kg}$ person $^{-1}$ year $^{-1}$ respectively, and its cultivation occurs in all regions of the country, in different times of the year, using different planting systems, being especially cultivated by family farming (Companhia Nacional de
Abastecimento - CONAB, 2019). Lately, the culture has become more visible among the great grain farmers of the country that make use of advanced technology such as phytosanitary control, mechanical harvest and irrigation. However, the production is still unstable due to various factors, including environmental stresses (Carbonell et al., 2014; Gonçalves et al., 2019). The characterization of different varieties becomes important to identify materials less susceptible to stressful conditions, which is critical to food security.

Regarding the Brazilian varieties, there are few studies about the influence of flooding in different phenological phases of the common bean. The damages caused by hypoxia may vary according to the phenological stages in which the plants are going through during the interaction with the stress factor.

The use of soils prone to waterlogging with species of economic importance depends on the identification of plants that can survive under conditions of low availability of soil oxygen as well as present good productivity for the farmer to make a profit. In recent years, several cultivars have been recommended by the breeding programs, the result of a joint effort by Brazilian Agricultural Research Corporation (EMBRAPA), state research institutions, universities, cooperatives, private companies and rural producers, which developed new cultivars with "carioca" type, combining good productivity and resistance to stresses and diseases (Carbonell et al., 2014).

Therefore, this study aimed to evaluate the responses of the common bean cultivar BRSMG-Uai when submitted to hypoxia in different phenological phases of its cycle. Considering that it is a relatively new cultivar, there are no studies on the physiological aspects under stressful environmental conditions, so we evaluated responses concerning gas exchange, carbohydrate metabolism, antioxidant metabolism, nitrate assimilation, growth and production.

\section{MATERIAL AND METHODS}

\section{Cultivation of plants and experiment conduction}

The experiment was conducted at the University of Lavras (UFLA), in Lavras, Brazil $\left(21^{\circ} 14^{\prime} 43 \mathrm{~S}\right.$ and $44^{\circ} 59>59 \mathrm{~W}, 920 \mathrm{~m}$ altitude). Seeds of the common bean (Phaseolus vulgaris L.), cultivar BRSMG-Uai, used for the experiment were developed by UFLA in association with University Federal of Viçosa (UFV), Brazilian Agricultural Research Corporation (EMPRAPA - rice and bean) and Minas Gerais Agricultural Research Corporation 
(Epamig). The cultivar is characterized as the carioca type, displaying erect architecture, with an indeterminate growth habit and life cycle of 80-90 days (Ramalho et al., 2016).

The seeds were sown in germination trays filled with vermiculite and sand (1:1). After eleven days, when the seedlings were in the V1 development stage (cotyledons at ground level), they were selected for uniformity in size and vigor. Afterward, they were transferred to polypropylene containers containing $40 \mathrm{~L}$ of nutrient solution (Hoagland; Arnon, 1950) and constant aeration. The common bean cultivar was placed in perforated styrofoam plates, being fixed by the hypocotyl of the seedlings so that only the root system was in contact with the nutrient solution (NS). The nutrient solution was changed weekly and the $\mathrm{pH}$ monitored daily, being adjusted to keep at $\mathrm{pH} 6.0 \pm 0.5$.

When they reached the phenological phase V3/ V4 (between the first and third trifoliated leaves), R6 (the anthesis of the first flower) and R7 (the coming forth of the first pods), the plants were subjected to hypoxia for nine days, when the plants showed strong reduction in stomatal conductance and show wilted leaves. Therefore, the aeration of the containers was suspended from some plants while other plants were kept under aeration as control ones (Figure 1).
The plant material was collected at the peak of stress (after nine days of induction) in each phenological phase, the aeration was restored and the remaining plant material was conducted until they completed their cultivation cycle to obtain the data for grain productivity (Figure 1).

The oxygen dissolved in the nutrient solution was quantified through titration based on the Winkler method with modifications (Pomeroy; Kirschman, 1945) in the Laboratory of Water Analysis (Laadeg, UFLA) to show the plants were under hypoxia. In the control containers, the oxygen was $7.6 \mathrm{mg} \mathrm{L}^{-1}$, whereas in the treatment without aeration, $4.9 \mathrm{mg} \mathrm{L}^{-1}$, that is, a reduction of $35 \%$ of available oxygen.

\section{Biometrical analyses}

The accumulation of biomass was determined by weighing the shoot and root dry matter after drying the plant material in a forced air oven kept at $65^{\circ} \mathrm{C}$ up to they presented constant mass. The number of leaves were assessed by directly counting them and the production components were assessed after the harvest and drying up of the pods by estimating the number of beans produced by plant and weight of 100 beans.

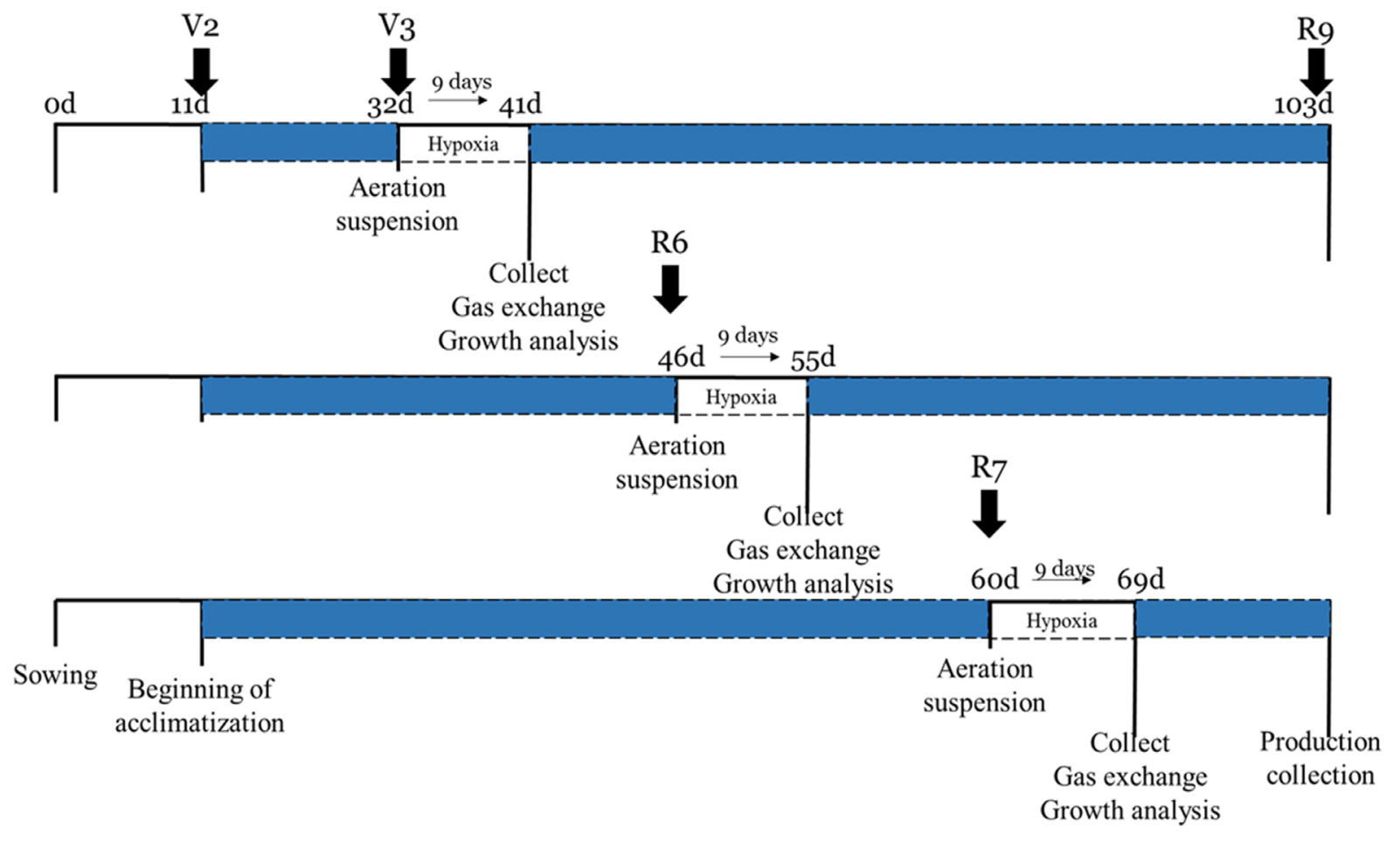

Figure 1: Schematic representation of the experimental period. 


\section{Gas exchange}

Gas exchange was measured utilizing an infrared gas analyzer (IRGA - LI6400XT Portable Phostosynthesis System, LI-COR, Lincoln, USA) and taking the central leaflet of the most recently expanded trifoliated leaf of the plants. All the measurements were conducted in clear days, between 9:30 a.m. and 10:30 a.m. We evaluated net photosynthesis $(A)$, stomatal conductance $(g s)$ and transpiration $(E)$ with a photosynthetic active radiation (PAR) of 1,200 $\mu \mathrm{mol} \mathrm{m}^{-2} \mathrm{~s}^{-1}$ (Nascimento et al., 2016). The mean leaf temperature in three days of measurements was $29.6 \pm 1.9^{\circ} \mathrm{C}$, the relative humidity $(\mathrm{RH})$ of the chamber was $49.6 \pm 7.9 \%$ and the $\mathrm{CO}_{2}$ partial pressure was $42 \pm 7 \mathrm{~Pa}$.

\section{Quantification of carbohydrates}

Carbohydrates were extracted from the shoot and root by homogenizing $0.2 \mathrm{~g}$ of dry matter, which was ground in a mill type Willey, with $5 \mathrm{~mL}$ of potassium phosphate buffer solution $100 \mathrm{mM}$ at $\mathrm{pH}$ 7.0, followed by placing the samples in a double boiler for 30 minutes at $40{ }^{\circ} \mathrm{C}$. The homogenate was centrifugated at $5.000 \mathrm{~g}$ for 10 minutes, collecting the supernatant.

The quantification of total soluble sugars (TSS) was estimated using the anthrone reagent method (Dische, 1962) and the reducing sugars (RS), using the protocol described by Miller (1959) and the DNS method. For starch, the protocol utilized was the one described by Zanandrea et al. (2010); and for sucrose, the one described by Van Handel (1968).

\section{Determination of antioxidant enzymatic activity}

The enzymatic extract was obtained through method described by Biemelt, Keetman and Albrecht (1998). The collected supernatant were used in enzymatic analysis of catalase (CAT) according to Havir and McHale (1987), superoxide dismutase (SOD) by the protocol of Giannopolitis and Ries (1977) and ascorbate peroxidase (APX) according to Nakano and Asada (1981).

\section{Determination of hydrogen peroxide and malonaldehyde}

Fresh leaves and roots $(0.2 \mathrm{~g})$ were macerated in liquid nitrogen with polyvinyl polypyrrolidone (PVPP), homogenized in $1.5 \mathrm{~mL}$ of $0.1 \%$ trichloroacetic acid (TCA) and centrifuged at $12,000 \mathrm{~g}$ for 15 minutes, at $4{ }^{\circ} \mathrm{C}$, collecting the supernatant. Lipidic peroxidation (MDA) was evaluated by quantification of reactive species of thiobarbituric acid, as described by Buege and Aust (1978). The content of $\mathrm{H}_{2} \mathrm{O}_{2}$ was determined according to Velikova, Yordanov and
Edreva (2000). Quantification was based on the standard hydrogen peroxide curve, with known concentrations.

\section{Determination of nitrate reductase activity}

The enzymatic extract was obtained from the maceration of $1.0 \mathrm{~g}$ of fresh root mass in liquid nitrogen by adding $5 \mathrm{~mL}$ of extraction buffer containing $100 \mathrm{mM}$ potassium phosphate buffer (pH 7.5), 1 mM PMSF, EDTA $100 \mathrm{mM}, 10 \%$ PVPP and $2 \mathrm{mM}$ DTT. The extract was centrifuged at $13,000 \mathrm{~g}$ for 20 minutes at $4{ }^{\circ} \mathrm{C}$ and the supernatant was collected for incubation. The activity of nitrate reductase (NR) was quantified utilizing the protocol described by Berges and Harrison (1995) with modifications.

\section{Statistic analyses}

The experiment was conducted in a completely randomized design with three treatments and six replicates (two plants by replicate). The data were subjected to ANOVA using Scott-Knott test and the means were then compared using Fisher's LSD at $\mathrm{P}<0.05$ with the aid of the software SISVAR ${ }^{\circledR}$ 5.6.

\section{RESULTS AND DISCUSSION}

For the best of our knowledge, there are no studies focused on the identification of the most critical period of common bean to low availability of oxygen (hypoxia) and there are no reports up to date for the cultivar BRSMGUai about its responses to hypoxia during its different phenological phases. In this work, the effect of hypoxia by suspension of aeration in the hydroponic cultivation was evaluated for this cultivar through variables that perform crucial roles in growth, grain production, carbohydrate metabolism, antioxidant metabolism and nitrate assimilation $\left(\mathrm{NO}_{3}^{-}\right)$.

Biometrical analyses performed in each phenological phase nine days after the aeration suspension allowed determining the performance of growth under low oxygen availability (Table 1). In general, the plants subjected to hypoxia suffered a reduction in the number of grains (NG) per plant (Figure 2), independently of the phenological phase in which the aeration was suspended. However, the greatest productivity loss was observed when the hypoxia happened during the V3/V4 stage with a reduction of nearly $83 \%$, suggesting a higher sensitivity to maintain productivity when the plant is in the vegetative growth phase. So, if the hypoxia happens during the vegetative phase, it seems there is a reduction in the accumulation of necessary biomass for the plant growth and development. 
Table 1: Net photosynthesis (A), stomatal conductance $\left(g_{s}\right)$ and total dry matter (DM) of common bean cultivar BRSMG-Uai subjected to hypoxia in phenological phases V3/V4, R6 and R7.

\begin{tabular}{ccccc}
\hline $\begin{array}{c}\text { Phenological } \\
\text { phase }\end{array}$ & Treatment & $\begin{array}{c}\mathrm{A} \\
\left(\mu \mathrm{mol} \mathrm{m}^{2} \mathrm{~s}^{-1}\right)\end{array}$ & $\begin{array}{c}\mathrm{g}_{\mathrm{s}} \\
\left(\mathrm{mol} \mathrm{m}^{2} \mathrm{~s}^{-1}\right)\end{array}$ & $\mathrm{DM}(\mathrm{g})$ \\
\hline \multirow{2}{*}{ V3/V4 } & Control & $24.5 \mathrm{~A}$ & $0.595 \mathrm{~A}$ & $7.19 \mathrm{~A}$ \\
& Hypoxy & $7.3 \mathrm{~B}$ & $0.042 \mathrm{~B}$ & $4.94 \mathrm{~A}$ \\
\hline \multirow{2}{*}{ R6 } & Control & $24.2 \mathrm{~A}$ & $0.599 \mathrm{~A}$ & $22.25 \mathrm{~A}$ \\
& Hypoxy & $4.5 \mathrm{~B}$ & $0.027 \mathrm{~B}$ & $16.90 \mathrm{~A}$ \\
\hline \multirow{2}{*}{ R7 } & Control & $21.9 \mathrm{~A}$ & $0.485 \mathrm{~A}$ & $40.61 \mathrm{~A}$ \\
& Hypoxy & $4.1 \mathrm{~B}$ & $0.024 \mathrm{~B}$ & $36.49 \mathrm{~A}$ \\
\hline
\end{tabular}

Treatments with the same letter do not differ statistically by the Scott Knott test at 5\% probability.

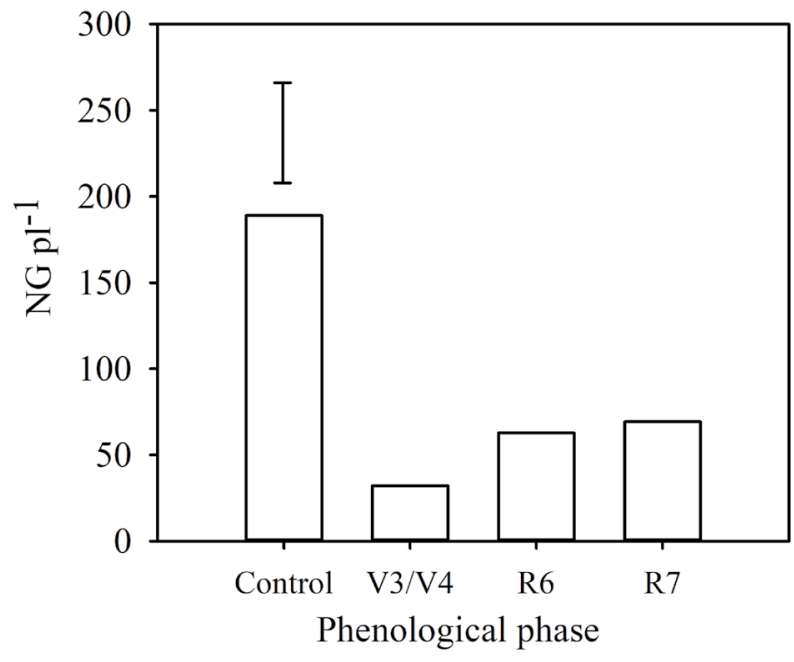

Figure 2: Number of grains (NG) per plant of common bean cultivar BRSMG-Uai when grown under hypoxia during the phenological phases V3/V4, R6 and R7 for. The means $(n=6)$ were tested by Fisher's LSD at $\mathrm{P}<0.05$.

Even though the lower yield had not happened as a consequence of the plant biomass reduction, the imposition of hypoxia occurred during the greatest growth rate of the culture, when the plants need normal conditions for oxygen availability (De San Celedonio; Abeledo; Miralles, 2018; Lake et al., 2019).

In the phenological phase $\mathrm{V} 3 / \mathrm{V} 4$ of the common bean, the third trifoliate is completely expanded, and the beginning of plant branching that starts in this phase, depends on biosynthetic processes, which is the result of the incorporation of new biomass and macromolecules, which, by turn, depends on the assimilated carbon from photosynthesis. The photosynthesis reduction due to the oxygen deficiency in the radicular system, is a systemic response caused by the stomatal closure (Table 1), which led to a decrease in rubisco carboxylation (Velasco et al., 2019). This reduced stomatal conductance was probably caused by an increase in $\mathrm{H}_{2} \mathrm{O}_{2}$ content in roots (Figure 3B) that may inhibit the activity of aquaporins or water channel proteins, reducing hydraulic conductivity and affecting directly the stomatal conductance (Silva et al., 2015; Maurel et al., 2016).

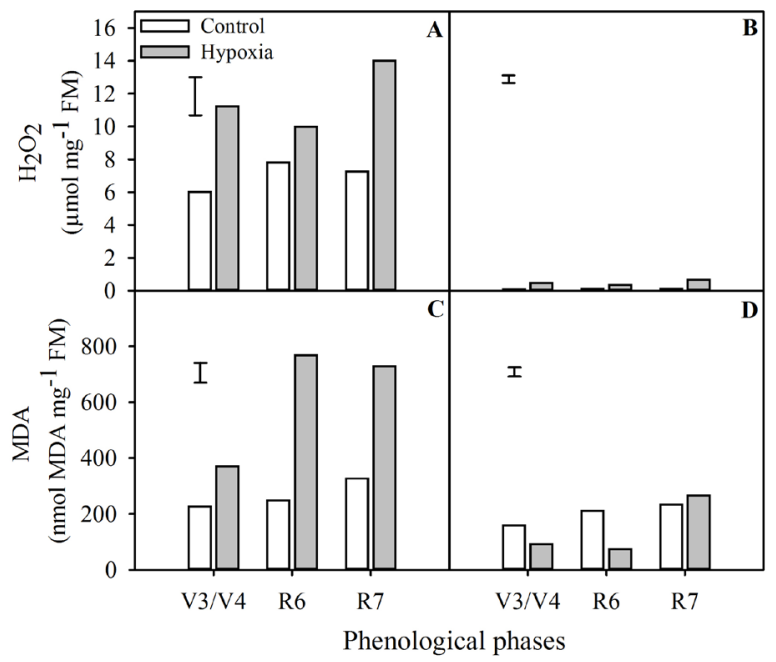

Figure 3: Content of hydrogen peroxide $\left(\mathrm{H}_{2} \mathrm{O}_{2}\right)$ and malondialdehyde (MDA) in leaves ( $A$ and $C$ ) and roots ( $B$ and $D$ ) of common bean cultivar BRSMG-Uai subjected to hypoxia in the phenological phases V3/ V4, R6 and R7. The means $(n=6)$ were tested by Fisher's LSD at $\mathrm{P}<0.05$.

The content of starch (Figure 4A), TSS (Figure 4C), RS (Figure 4E) and sucrose (Figure 4G) in leaves increased under hypoxia in all phenological phases. However, it was expected a decline in the contents of starch, TSS and sucrose caused by the stimulation of glycolysis, as an attempt to supply the ATP demand for the plant, due to $\mathrm{O}_{2}$ availability decrease. The accumulation of pyruvate (final product in the glycolytic via) may trigger the fermentative pathway, which is key to the regeneration of $\mathrm{NAD}^{+}$ utilized as a coenzyme in the glycolytic via. Thus, it is possible that the increase in nonstructural carbohydrates in V3/V4, which would beforehand attend the demands of vegetative growth, happens due to the restriction of assimilate translocation to the roots caused by lack of 
available $\mathrm{O}_{2}$, which corroborates with the fact that there is no increase in carbohydrates in the roots (Figure 4B, D, F and $\mathrm{H}$ ). Variations in the sugar content in leaves may still be attributed to different degrees of starch degradation, carbon allocation into plant biomass and the use of those carbohydrates in respiratory metabolism, depending on the plant age (Fukao et al., 2019).

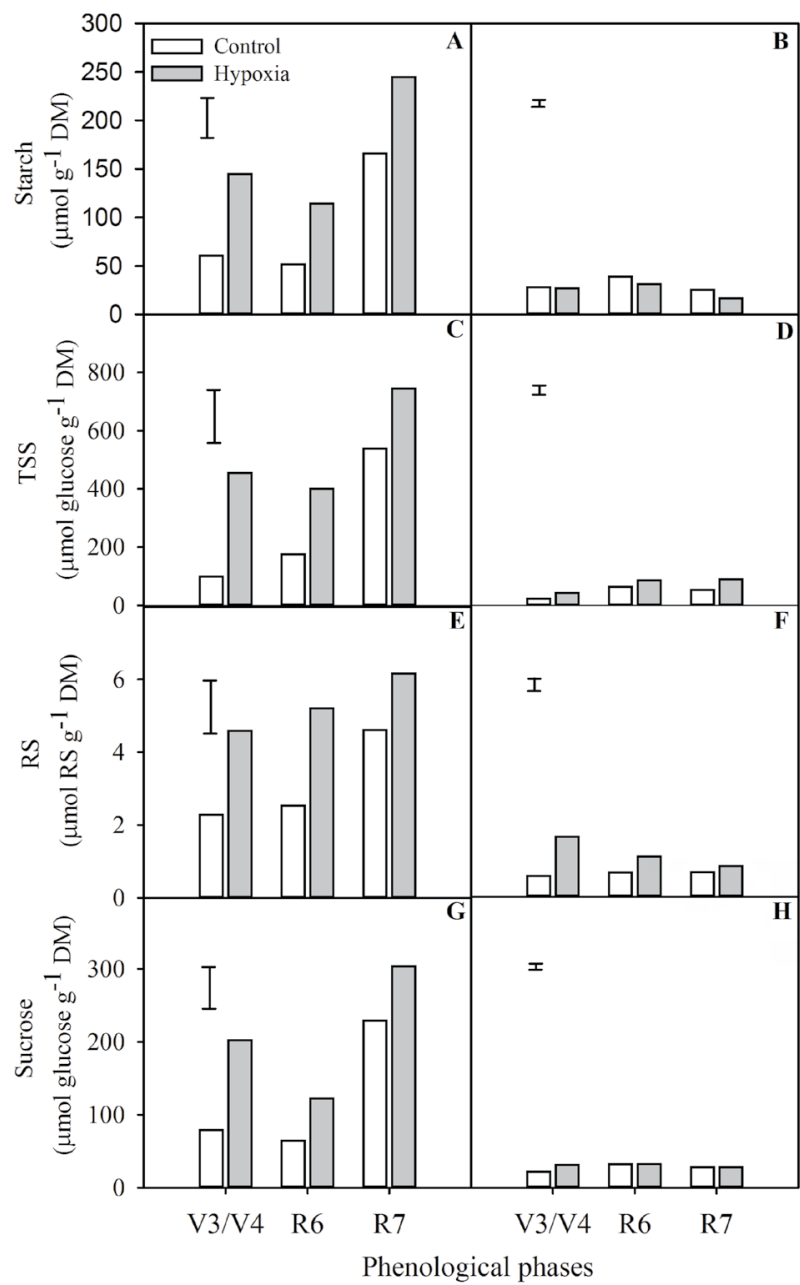

Figure 4: Concentration of starch, total soluble sugars (TSS), reducing sugars (RS) and sucrose in leaves ( $A$, $C, E$ and $G$ ) and roots ( $B, D, F$ and $H$ ) of the common bean cultivar BRSMG-Uai subjected to hypoxia in the phenological phases V3/V4, R6 and R7. The means $(n=6)$ were tested by Fisher's LSD at $P<0.05$.

It is important to consider that triggering the fermentative pathway for very long periods promotes the accumulation of toxic oxidative products, such as ethanol and ROS (Dumont; Rivoal, 2019) causing damage to the plants. The extend of the oxidative stress in plant tissues may be determined by quantifying de MDA that is an indicator of lipidic peroxidation. The activity of SOD in leaves presented a reduction in V3/V4 (Figure 5A), even with an increase in $\mathrm{H}_{2} \mathrm{O}_{2}$ (Figure 3A) and MDA (Figure 3C) in all phenological phases evaluated, indicating that $\mathrm{H}_{2} \mathrm{O}_{2}$ formation may have come from the photorespiratory via. In that via, glycolate is oxidized into glyoxylate and $\mathrm{H}_{2} \mathrm{O}_{2}$ by glycolate oxidase in the peroxisomes (Czarnocka; Karpiński, 2018).

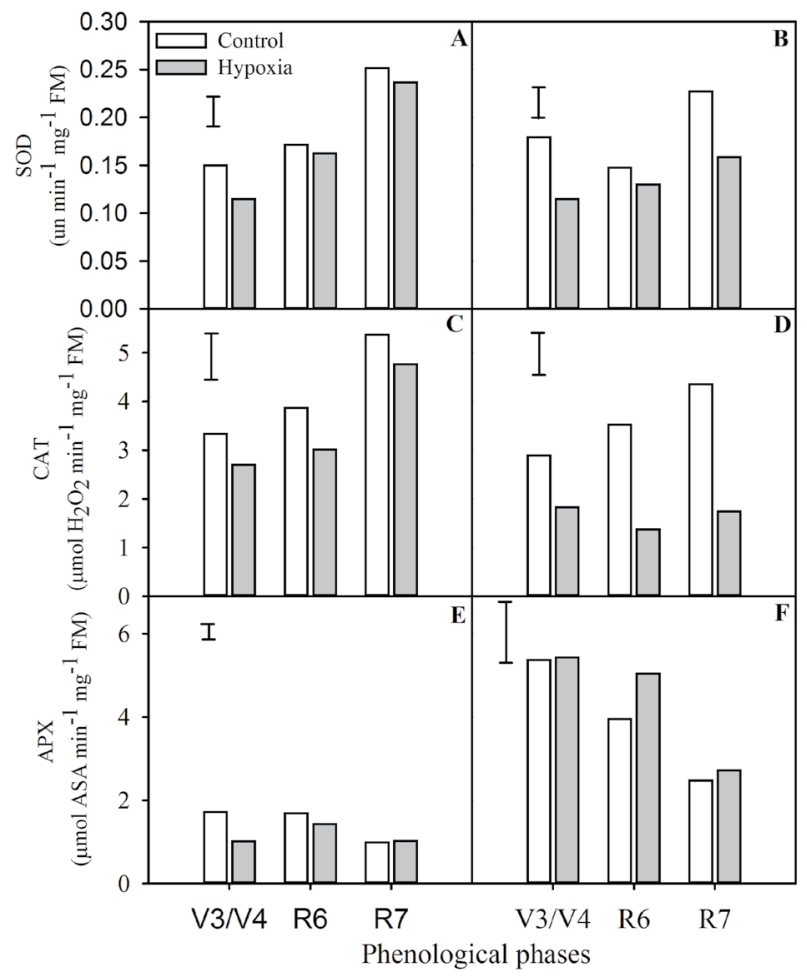

Figure 5: Activity of the enzymes superoxide dismutase (SOD), catalase (CAT) and ascorbate peroxidase (APX) in leaves $(A, C$ and $E$ ) and roots $(B, D$ and $F)$ of common bean cultivar BRSMG-Uai subjected to hypoxia in the phenological phases V3/V4, R6 and R7. The means $(n=6)$ were tested by Fisher's LSD at $P<0.05$.

Hydrogen peroxide is a ROS moderately reactive, whose small size allows it to go through cell membranes and migrate to different compartments, spreading the damage and acting as a signal or messenger to stress conditions (Singh, et al., 2016; Karuppanapandian et al., 2011). In optimal physiological conditions, there 
is a balance between $\mathrm{H}_{2} \mathrm{O}_{2}$ production and antioxidant enzymatic activity, nonetheless, in this study, the exposition of plants to hypoxia resulted in a lower activity of the enzyme CAT in the roots (Figure 5D) in V3/V4 and R6. Nevertheless, in leaves, after the suspension of aeration, the antioxidant system was not efficient enough to avoid the increase of lipidic peroxidation (Figure 3C), in none of the phenological phases evaluated.

The activity of NR (Figure 6) in the roots was $42 \%$ greater under hypoxia in $\mathrm{V} 3 / \mathrm{V} 4$, when compared to control plants. The increase in this enzyme activity may be related to the regeneration of the electron carrier $\mathrm{NAD}^{+}$ in the cytosol, as an alternative to fermentative pathways since the plant will accumulate less toxic compounds in the cells (De Carvalho et al., 2015). It occurs under lower competition demand for that reducing power with the enzymes lactate dehydrogenase and alcohol dehydrogenase, contributing, therefore, to a higher use and maintenance of glycolysis (Fukao et al., 2019). Moreover, NR contributes to an increase in nitrogen compounds. Although there was a reduction of amino acid in V3/V4 in roots, a large content of proteins in leaves (Figure 7) also suggests that these molecules may have been remobilized to that organ causing, therefore, an increase in protein synthesis in the shoot.

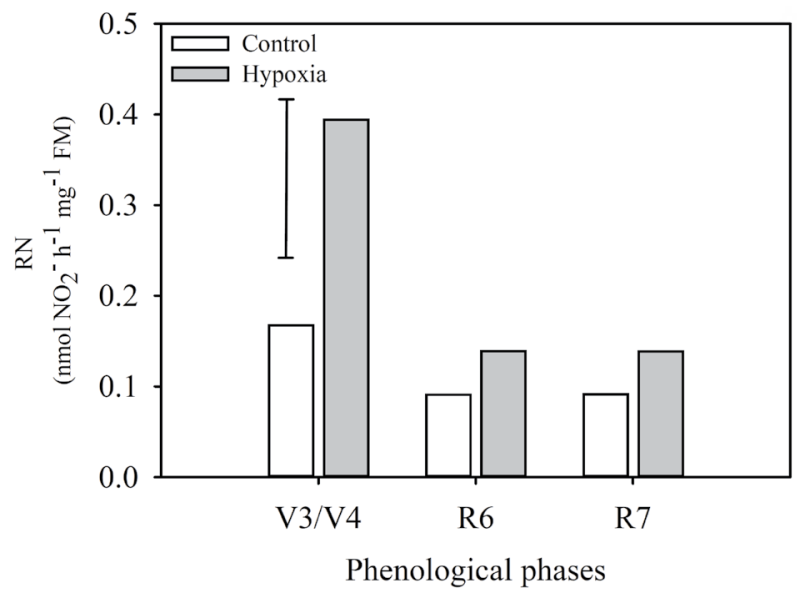

Figure 6: Nitrate reductase activity in roots of common bean cultivar BRSMG-Uai subjected to hypoxia in the phenological phases V3/V4, R6 and R7. The means $(n=6)$ were tested by Fisher's LSD at $P<0.05$.

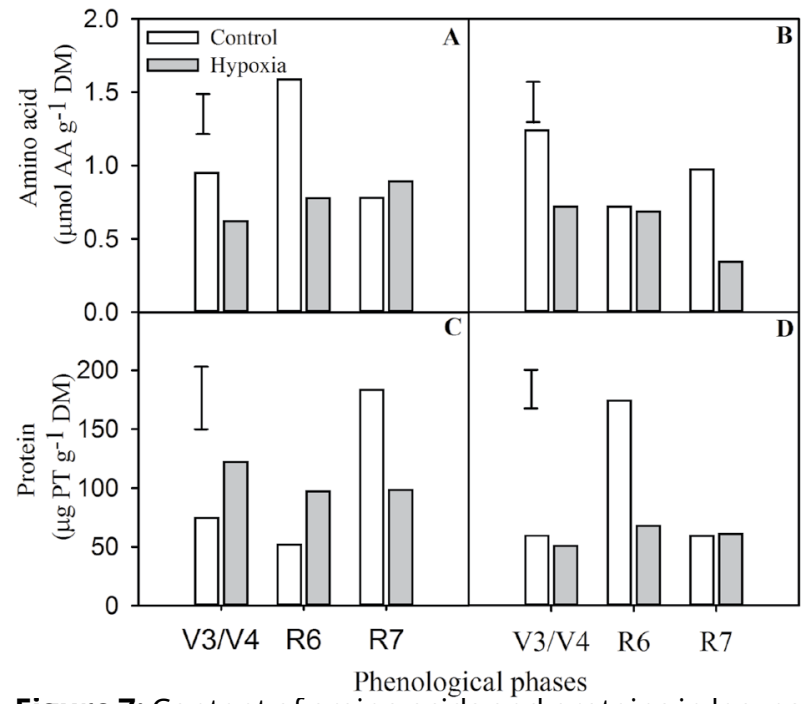

Figure 7: Content of amino acids and proteins in leaves ( $A$ and $C$ ) and roots ( $B$ and $D$ ) of common bean cultivar BRSMG-Uai subjected to hypoxia in phenological phases V3/V4, R6 and R7. The means $(n=6)$ were tested by Fisher's LSD at $\mathrm{P}<0.05$.

\section{CONCLUSIONS}

The cultivar BRSMG-Uai presented high sensibility to low $\mathrm{O}_{2}$ availability in the root system. Bean yield is affected in an independent manner of phenology when submitted to hypoxia, however, considering the phenological phases evaluated, V3/V4 is the most critical to productivity. Nitrate reductase enzyme displayed high activity in roots under hypoxia in the phenological phase $\mathrm{V} 3 / \mathrm{V} 4$, contributing to an increase of synthesis of nitrogen compounds. The antioxidant system was not efficient enough to prevent increases in lipid peroxidation in any of the evaluated phenological phases.

\section{ACKNOWLEDGMENTS}

The authors would like to thank the Coordination for the Improvement of Higher Education Personnel (CAPES, Financial Code - 001), the National Council for Scientific and Technological Development (CNPq) and Fundação de Amparo a Pesquisa do Estado de Minas Gerais (FAPEMIG) for having financed part of the project. 


\section{REFERENCES}

BERGES, J. A.; HARRISON, P. J. Nitrate activity quantitatively predicts the rate of nitrate incorporation under steady state light limitation: A revised assay and characterization of the enzyme in three species of marine phytoplankton. Limnology and Oceanography, 40(1):82-93, 1995.

BIEMELT, S.; KEETMAN, U.; ALBRECHT, G. Re-aeration following hypoxia or anoxia leads to activation of the antioxidative defense system in roots of wheat seedlings. Plant Physiology, 116(2):651-658, 1998.

BUEGE, J. A.; AUST, S. D. Microsomal lipid peroxidation methods. Enzymology, 52:302-310, 1978.

CARBONELL, S. A. M. et al. 'IAC Milênio' - Common bean cultivar with high grain quality. Crop Breeding and Applied Biotechnology, 14(4):273-276, 2014.

DE CARVALHO, P. A. et al. Nitrogen metabolism in the roots of rubber tree (Hevea brasiliensis) plants supplied with nitrate or ammonium as nitrogen source during hypoxia. Australian Journal of Crop Science, 9(12):1278, 2015.

CHOUDHURY, S. et al. Reactive oxygen species signaling in plants under abiotic stress. Plant Signaling \& Behavior, 8(4):e23681-1, 2013.

COMPANHIA NACIONAL DE ABASTECIMENTO - CONAB. Acompanhamento de safra brasileira: Grãos - V. 60 , safra 2018/2019. Décimo primeiro levantamento. Brasília, DF. 45p. 2019.

CZARNOCKA, W.; KARPINSKI, S. Friend or foe? Reactive oxygen species production, scavenging and signaling in plant response to environmental stresses. Free Radical Biology and Medicine, 122:4-20, 2018.

DE SAN CELEDONIO, R. P.; ABELEDO, L.; MIRALLES, D. J. Physiological traits associated with reductions in grain number in wheat and barley under waterlogging. Plant Soil, 429:469-481, 2018.

DEBORTOLI, N. S. et al. An index of Brazil's vulnerability to expected increases in natural flash flooding and landslide disasters in the context of climate change. Natural Hazards, 86(2):557-582, 2017.

DUMONT, S.; RIVOAL, J. Consequences of oxidative stress on plant glycolytic and respiratory metabolism. Frontiers in Plant Science, 10:1-16, 2019.

DISCHE, Z. General color reactions. In: WHISTLER, R. L.; WOLFRAM, M. L. Carbohydrate Chemistry. New York: Academic Press, p.477-520, 1962.
FUKAO, T. et al. Submergence and waterlogging stress in plants: a review highlighting research opportunities and understudied aspects. Frontiers in Plant Science, 10:340, 2019.

GIANNOPOLITIS, C. N.; RIES, S. K. Superoxide dismutase: Occurrence in higher plants. Plant Physiology, 59(2):309314, 1977.

GONÇALVES, J. G. R. et al. Drought tolerance evaluated in common bean genotypes. Ciência e Agrotecnologia, 43:e001719, 2019.

HAVIR, E. A.; MCHALE, N. A. Biochemical and developmental characterization of multiple forms of catalase in tobbaco leaves. Plant Physiology, 84(2):450-455, 1987.

HIRABAYASHI, Y. et al. Global flood risk under climate change. Nature Climate Change, 3(9):816-821, 2013.

HOAGLAND, D. R.; ARNON, D. I. The water culture method for growing plants without soil. California Agriculture Experimental Station Circular, 347:1$32,1950$.

KARUPPANAPANDIAN, T. et al. Reactive oxygen species in plants: Their generation, signal transduction, and scavenging mechanisms. Australian Journal of Crop Science, 5(6):709-725, 2011.

LAKE, L. et al. Yield determination and the critical period of faba bean (Vicia faba L.). Field Crops Research, 241:107575107579, 2019.

LAL, M. et al. Reactive oxygen species, reactive nitrogen species and oxidative metabolism under waterlogging stress. In: HASANUZZAMAN, M. et al. (Eds.). Reactive Oxygen, Nitrogen and Sulfur Species in Plants: Production, Metabolism, Signaling and Defense Mechanisms, Chapter 34, p.777-812, 2019.

LEE, S. C. et al. Molecular characterization of the submergence response of the Arabidopsis thaliana ecotype Columbia. New Phytologist, 190(2):457-471, 2011.

MAUREL, C.; VERDOUCQ, L.; RODRIGUES, O. Aquaporins and plant transpiration. Plant, Cell \& Environment, 39(11):2580-2587, 2016.

MILLER, G. L. Use of dinitrosalicylic acid reagent for determination of reducing sugar. Analytical Chemistry, 31(3):426-428, 1959.

NAKANO, Y.; ASADA, K. Hydrogen peroxide is scavenged by ascorbato-specific peroxidase in spinach chloroplasts. Plant \& Cell Physiology, 22(5):867-880, 1981. 
NASCIMENTO, A. L. V. do et al. Physiological and agronomical responses of common bean subjected to tryptophol.Annals of Applied Biology, 168(2):192202, 2016.

PEREZ-JIMENEZ, M. et al. Are commercial sweet cherry rootstocks adapted to climate change? Short-term waterlogging and $\mathrm{CO}_{2}$ effects on sweet cherry cv. 'Burlat'. Plant, Cell \& Environment, 41(5):908-918, 2017.

POMEROY, R.; KIRSCHMAN, D. Determination of dissolved oxygen proposed modification of the winkler method. Industrial And Engineering Chemistry, 17(11):715-716, 1945.

RAMALHO, M. A. P. et al. BRSMG Uai: common bean cultivar with carioca grain type and upright plant architecture. Crop Breeding and Applied Biotechnology, 16(3):261264, 2016.

SASIDHARAN, R. et al. Community recommendations on terminology and procedures used in flooding and low oxygen stress research. New Phytologist, 214(4):14031407, 2017.
SILVA, K. I. et al. Short-term physiological changes in roots and leaves of sugarcane varieties exposed to $\mathrm{H}_{2} \mathrm{O}_{2}$ in root medium. Journal of Plant Physiology, 177(1):93-99, 2015.

SINGH, R. et al. Reactive Oxygen Species (ROS): Beneficial companions of plant's developmental processes. Frontiers in Plant Science, 7:1-8, 2016.

VAN HANDEL, E. Direct microdetermination of sucrose. Analytical Biochemistry, 22(2):280-283, 1968.

VELASCO, N. F. et al. Photosynthetic responses and tolerance to root-zone hypoxia stress of five bean cultivars (Phaseolus vulgaris L.). South African Journal of Botany, 123:200207, 2019.

VELIKOVA, V.; YORDANOV, I.; EDREVA, A. Oxidative stress and some antioxidant systems in acid rain-treated bean plants. Plant Science, 151(1):59-66, 2000.

ZANANDREA, I. et al. Tolerance of Sesbania virgata plants to flooding. Australian Journal of Botany, 57(9):661-669, 2010.

ZHANG, Y. et al. Growth, lint yield and changes in physiological attributes of cotton under temporal waterlogging. Field Crops Research, 194:83-93, 2016. 